
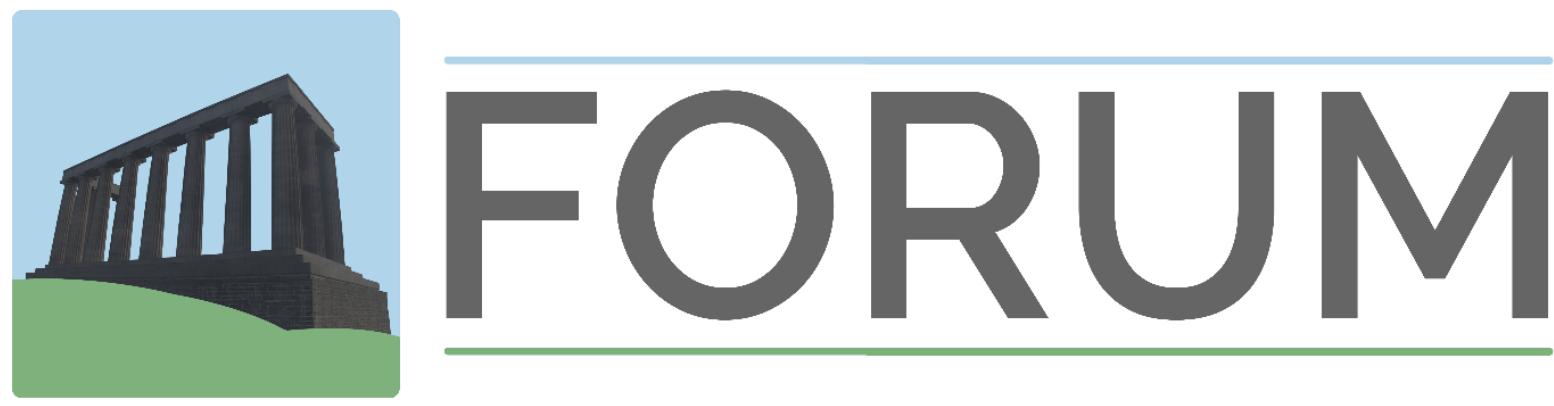

University of Edinburgh

Postgraduate Journal of Culture and the Arts

Issue 27 | Autumn 2018

Title

Wilkie Collins and Oscar Wilde: Challenging Intersections Between the Male and Female Gaze in Victorian Popular Literature

Author

Leah Henderson

Publication

FORUM: University of Edinburgh Postgraduate Journal of Culture \& the Arts

Issue Number 27

Issue Date

Autumn 2018

Publication Date 21/12/2018

Editors

Valentina P. Aparicio and Rachel Chung

FORUM claims non-exclusive rights to reproduce this article electronically (in full or in part) and to publish this work in any such media current or later developed. The author retains all rights, including the right to be identified as the author wherever and whenever this article is published, and the right to use all or part of the article and abstracts, with or without revision or modification in compilations or other publications. Any latter publication shall recognise FORUM as the original publisher. 


\section{Wilkie Collins and Oscar Wilde: Challenging Intersections Between the Male and Female Gaze in Victorian Popular Literature}

\section{Leah Henderson \\ Griffith University}

Wilkie Collins's The Woman in White (1860) and Oscar Wilde's The Picture of Dorian Gray (1890) are novels significant for their distinct awareness of the socio-political power of the gaze. In this essay, I will reveal how these authors use the male and female gaze in similar and contrasting ways. In particular, I shall explore the ways they denounce the patriarchal Victorian system, which renders the act of gazing a power that is both objectifying and degrading. Gazing enacts itself to varying degrees through the social hierarchy, indicating whom can objectify whom, and can enact upon what they choose to see. This hierarchy of Victorian English society is so varied by class, wealth, gender, and race that the gaze in these texts does not always operate in the same way. These complicated intricacies of the gaze are what make these novels require such in-depth analysis, because of the multiple ways in which the gaze can work according to individual scenarios. Both authors portray these complicated intricacies by using both the male and female gaze in the text. While academic critique usually separates these two gazes due to their gender, the novels of Collins and Wilde reveal how important it is to study them together, because while the gaze affects people individually, it is essentially a collective interaction. Collins and Wilde take separate approaches in depicting the gaze: the former testing the capability of the reader to look beyond the coercive statements of the first-person narrator, and the latter an omnipresent third-person narrator. Together, these different approaches increase reader understanding of the mechanical workings of the gaze and therefore complements a comparative analysis of the two novels.

Wilkie Collins's The Woman in White (1860) and Oscar Wilde's The Picture of Dorian Gray (1890) are novels significant for their distinct awareness of the socio-political power of the gaze, as they reveal to the reader the systematic normalcy of the gaze in everyday living. More specifically, they portray gazing to varying degrees through the social hierarchy, indicating who can objectify whom, and who can act upon what they choose to see. This hierarchy of Victorian English society is so varied by class, wealth, gender, and race that the gaze in these texts does not always operate in the same way, but according to individual scenarios. Collins and Wilde illustrate this in their novels by portraying both the male and female gaze to reveal various types of objectification. In this essay, I will discuss how these authors use the male and female gaze in similar and contrasting ways. In particular, I will explore the ways in which they denounce the patriarchal Victorian system, which renders the act of gazing a power that is both objectifying and degrading. Indeed, following John Berger's Ways of Seeing (1972), which focuses on the detrimental effects of the male gaze upon women, a polarised scholarship has risen in which scholars analyse either the male or the female respectively, yet not so much on how these divided gazes interact together, particularly when simultaneously occupying the same space. Looking at the 
novels of Collins and Wilde reveals the importance of studying them together because, while the gaze affects people individually, it is essentially a collective interaction.

Wilde and Collins portray both the male and female gaze as objectifying, although the effects of the female gaze are less destructive than their male counterparts, in accordance with the patriarchal hierarchy. Wilde's novel posits an anti-male gaze and criticises the superficiality of nineteenth-century London. Similarly, Collins's novel scrutinises the male gaze by revealing the greed and corruption of privileged men, who steal the identities and money of wealthy women in order to achieve an extravagant lifestyle and maintain social status. The text recounts the identity swap of Laura Glyde, née Fairlie, and Anne Catherick by his two main protagonists, Walter Hartright and Marian Halcombe. On the surface, both accounts appear to synchronise and complement each other, but a closer textual analysis of these accounts raises a lot of questions, particularly about the truthfulness of what is being stated. As John Berger states, 'a large part of seeing depends upon habit and convention,' (Ways of Seeing 0o:01:10-13) and thus the reader must remain sceptical of the narrator's first-person account. Collins's implementation of two main narrators of opposite sex more clearly reveals how the male and female gaze interact: these gazes are based on the assumptions people make about each other's appearances, and work as a hidden dialogue behind what is actually being said and done by the characters throughout the text. Indeed, the gazes in these two novels are not only factored by gender, but also by class, wealth, and race: for example, Count Fosco is the mysterious foreign outsider who is subjected to a very denigrating observation by Marian; however, Lord Glyde, the other villain, is not. This is the same for Wilde's novel, which uses ironic satire to confuse the object of art with human beings who are treated like objects to be admired. Wilde explores the idea of reciprocation; in contradiction to Berger's argument that 'women look at women' and 'women watch themselves being looked at,' (Ways of Seeing oo:00:02-13) sometimes the one who is being looked at looks back. Basil Hallward, the painter, and Lord Henry, the indulging mentor, gaze at Dorian; Dorian gazes at love interests Sybil Vane and Hetty Merton, who then gaze back at him.

In The Picture of Dorian Gray, Dorian's portrait is the centrepiece of the novel, and its beauty carries the story. The preface of the novel begins with Wilde's own definition of art, in which he describes 'all art' as being 'quite useless', and says that 'the only excuse for making a useless thing is that one admires it intensely' (4). This argument is a central idea for Wilde throughout the novel, and reveals the downfall of Dorian Gray, who takes the beauty of his own portrait further than its superficiality can account for. This art, in particular, is admired far too intensely, and symbolises the issue of gazing at large, particularly when the characters repeatedly behave according to these observations of what is considered beautiful and deserving of admiration, and what should be ignored or criticised. This latter aspect causes people to selfishly and repeatedly hurt each other, whilst feeling justified throughout the whole novel.

As Berger argues, European oil painting was traditionally about displaying one's wealth and social status. Portraiture, in particular, was about becoming 'an object of respect and envy' (Ways of Seeing 00:15:25). Dorian Gray's portrait is no exception: Chapter One begins while the artist Basil Hallward is finishing painting a portrait of Dorian, the young man who unknowingly owns Basil's adoration and love. The painting encapsulates Dorian's youth and beauty to such lengths that the vain Dorian admits to simultaneously loving it and envying it (25). Already, the reader recognises that this 
essentially 'useless' painting is being taken too seriously by its subject when Dorian proclaims his wish to 'always to be young, and the picture... to grow old,' that he 'would give [his] soul for that!' (Wilde 24). Christopher Craft believes that Wilde's novel is 'his appropriation of Ovid's' Metamorphoses' (110), the legend in which Narcissus falls in love with his own reflection, with the slight difference that Narcissus was not under an external influence. Dorian, on the other hand, only falls in love with his own image because people are always remarking upon his beauty. Not only do Lord Henry and Basil Hallward admire Dorian's looks through the painting, but there is constant comparison between the art and the actual subject. According to Craft, 'Wilde explicitly duplicates the mirror function' when Dorian imitates this act of gazing upon himself by the use of a mirror, and also compares himself to the picture (109). Furthermore, the author illustrates these doubling actions through the words of the text, so that by the time the reader interprets this scene, the act of gazing has tripled. This illuminates the chain reaction of gazing and how this chain is a continuous cycle within everyday life and society.

Dorian is both reliant on and takes advantage of the gazes of others, exploiting the exposed weakness of those entranced by his beauty. His repeated use of the hand mirror indicates this because, while this is a very personal reflection, these mirrors are only ever used in confirming the opinions of others. As Dorian is pleased to see in the little golden hand mirror engraved with cupids given to him by Lord Henry, no 'lines of cruelty' had 'warped his red lips' as they did in the painting (Wilde 73). As the painting continues to grow hideous and haggard, Dorian remains young and beautiful, locking the painting away like a deep shameful secret from the rest of society. Furthermore, the act of tripling reinforces the symbolic motif of Dorian Gray's portrait.

In Ways of Seeing, John Berger discusses nineteenth-century European art as objectifying nude subjects for the sexual pleasure of the artist and viewers of the painting, while the subject remains passive. But while Berger talks specifically about the ways in which 'men look at women,' and 'women watch themselves being looked at' (Ways of Seeing 00:00:02-13), Wilde discusses the homoerotic gaze during a time when homosexuality was still illegal, and, with the exception of public scandals, was largely ignored in Victorian society. Not only does Wilde reveal how the gaze is objectifying and superficial, he also reveals how heterosexual gazes, in which the subject becomes an object of sexual desire, are considered socially acceptable, while homoerotic gazes are forbidden. For instance, Dorian has multiple female admirers who, though mature, upper-class and married, are able to freely engage in an extra-marital affair with a young bachelor because of their social positions.

The division between homoerotic repression and heterosexual privilege is visualised through the relationship dynamics among Basil, Dorian, and Lord Henry. While Basil has inadvertently indulged Dorian's vanity through the painting, Lord Henry deliberately influences Dorian's indulgence for his own personal satisfaction. Lord Henry does not gaze at Dorian sexually, but rather as a pupil studying his privileged status in society. Lord Henry is not satisfied with just gazing from afar; he wants to act on these observations and manipulate Dorian for his own amusement, stroking his own ego as the benevolent tutor. Once Dorian has become infatuated with Sybil Vane, Lord Henry reflects smugly to himself that 'it was through certain words of his, musical words said with musical utterances, that Dorian Gray's soul had turned to this white girl and bowed in worship before her' (Wilde 47). Later, he also proclaims that 'Dorian Gray was a subject made to his hand, and seemed to promise rich and fruitful results' (Wilde 48-49). This demonstrates to the reader not just what people are thinking and feeling 
when they are looking, but how they put these thoughts and feelings into action. Lord Henry, a man of age, privilege, wealth and status, observes the beautiful Dorian and knows that he is able to exploit him due to his lower rank within the social hierarchy.

Wilde's portrayal of the male gaze is comparable to the gaze of the male protagonist in Wilkie Collins' The Woman in White (1860). Unlike Lord Henry's upper-class status, Walter Hartright is a drawing master, employed in a position of servitude by the wealthy Mr Fairlie to tutor his privileged wards, Laura Fairlie and Marian Halcombe. Although Collins does not directly indicate that this difference in class is personally problematic for Walter, he suggests subconscious resentment of their gender. Because Walter is male, he assumes a patronising, authorial eye over the two women's physical attractiveness, facial beauty, and choice of dress, as the determinates of their character, thus transferring his inferior class status. Indeed, this is how Walter retains dignity, particularly when Laura, his love interest, is betrothed to marry the powerful and influential Lord Glyde. Tamar Heller argues that 'although Hartright devotes himself to restoring Laura's stolen identity, and thus symbolically to the cause of rectifying women's weakened legal status, his path tends away from a total identification with the disenfranchised' (127). This lack of 'total identification' is recognisable, according to Heller, in Hartright's continual 'efforts to consolidate his male protagonist's position as a professional man,' implicating him within the institutional powers that victimise women (127). Rather than destroying existing structures, Walter's narration indicates what reforms he feels should be made, thus enacting his simultaneous role as protagonist and patroniser.

This assumption of rank is also prevalent in the physical structure of the text: Walter occupies the narration in the first and third volume, meaning that he introduces the main characters through his perspective - he is constantly influencing the reader's impressions of the key characters involved in the scandal, and then he has the final word at the end of the story. While Marian narrates the second volume, her diary entries only fill the middle part of the story, from which Walter is absent. Even when Marian rescues Laura from her false imprisonment in the asylum, this pivotal moment is merely summarised in the third volume, underplaying Marian's masculine and heroic role in saving Walter's love. These considerations, as well as Walter's simultaneous role as protagonist and patroniser, question how much Walter is actually fighting to defend the rights of women, and to what extent he is acting in his own self-interest. As Tamar Heller points out, Walter is the one who assumes the authority 'as editorin-chief' after both accounts of the Lady Glyde affair have been compiled together, even going so far as 'to delete' parts of Marian's text (115). This reveals that Walter 'has as much at stake in controlling the novel's female voices as' the antagonists of the texts, 'Glyde and Fosco, the more obviously chauvinistic figures, have in taming the novel's women' (Heller 115). Although Marian is scathingly observed through Walter's eyes at the beginning of the text, Marian does not have the privilege to reciprocate this gaze upon Walter in her own diary entries. He could, in fact, be a toad, and the reader would be none the wiser. Upon beginning his tutoring position at the Fairlie household, Walter meets Marian first. He enters the drawing room while she is unaware and observes from a distance that 'her figure was tall, yet not too tall; comely and well-developed, yet not fat; her head set on her shoulders with an easy, pliant firmness; her waist, perfection in the eyes of a man' (Collins 34). Walter's evaluation of Marian's figure as 'perfection in the eyes of a man' highlights the sexual objectification through the male gaze, much like the oil paintings discussed by Berger, in which the female figures serve simply to please the viewer. 
The struggle for social power is evident among Walter's subconscious intentions, because he would not otherwise have emphasised in so much detail this first impression of Marian, as it has no bearing on the rest of the narrative.

However, this distant observation also builds up the reader's expectation that Marian will be his romantic interest: 'The easy elegance of every movement of her limbs and body as soon as she began to advance from the far end of the room, set me in a flutter of expectation to see her face clearly' (Collins 34). This anticipation proves anticlimactic when Marian 'approaches nearer' and Walter realises that, to his standard of beauty, 'The lady is ugly!' (Collins 34). As a result, Walter does not fall in love with Marian, but with the beautiful Laura. Even so, Walter cannot help pointing out Laura Glyde's facial 'blemishes' despite being in love at first sight (Collins 51-52): he notes that her nose 'missed the ideal straightness' and that 'the lower part of the face is too delicately refined away towards the chin to be in full and fair proportion with the upper part' (Collins 51). Luckily for Laura, because Walter has immediately fallen in love, he claims that 'it is not easy to dwell' on these perceived flaws (Collins 52). As Laura is to inherit, and not Marian, this observation can also be seen as a tactical narration by Walter to mask a possible ulterior motive. For indeed, even as it becomes obvious that Walter is looking for love, it clearly coincides with the fortune included in marrying Laura. As Matthew Sweet argues, 'Lies are told; texts invade other texts. The bundle of documents that we are handed might be a full and true account of the Laura Glyde Affair. On the other hand, these papers might be the self-justifying trickery of their editor' (xxxi). Collins repeatedly reminds his readers that the gaze is always subjective, and sometimes subversive.

The most striking difference between the works Collins and Wilde is the choice of narration. Collins uses the gaze within first-person accounts, and the reader has to sort through constant subjectivity without the reassurance of a reliable and impartial voice. On the other hand, Wilde's thirdperson narration portrays characters in the act of gazing; they observe under their own subjective eyes, but the reader is aware that the narrator does not share these judgments. With a set-list of characters who are gazing and prioritising youth and beauty above all else, it is hard to find a true protagonist in this moralistic tale - there are merely antagonists and victims - clearly suggesting that Wilde has written a fable about the consequences of accepting appearances superficially. The most tragic consequence happens when Dorian becomes completely infatuated with Sybil Vane while viewing her performance of Romeo and Juliet at a local theatre. Dorian proclaims that Sybil 'was the loveliest thing I had ever seen in my life' (Wilde 45). To him, Sibyl only deserves his love because of her perceived flawlessness, and her super-human status, as he continues to describe her as 'all the great heroines of the world in one' (Wilde 45), foreshadowing her doomed fate to become a martyr. The symbolism of Sybil Vane's last name posits her as the object of Dorian's vanity through his idealised infatuation. Dorian is constantly attending the theatre to admire her acting performances of female martyrs “"Tonight she is Imogen," he answered, 'and tomorrow night she will be Juliet' (Wilde 45) - emphasising the importance placed on physical appearance, and the accordingly high expectations of perfection that are promised with such beauty. It continues to escape Dorian's attention that she is merely acting, until one night, when her performance is less than exemplary and the illusion shatters: after the show, Dorian self-righteously denounces her: 'You used to stir my imagination. Now you don't even stir my curiosity... You are nothing to me now' (Wilde 71). Wilde posits the male gaze, not as a measure of worth, but as a 
cruel practice that punishes women for failing to meet idealised standards, particularly those set by mythical and legendary female figures. The reader dismays when a heartbroken Sibyl commits suicide, while an apathetic Dorian quickly forgets.

Wilde also remarks upon the female gaze. When the pair first meets, Sibyl remarks that Dorian appears 'more like a prince,' and therefore she must address him as 'Prince Charming' (Wilde 45). Using the name Prince Charming alludes to Sybil's expectations that Dorian will complete her life because his youth and beauty fit the archetypal description of a prince. When the opposite happens, the blow is devastating. These notions of Prince Charming are reiterated in Dorian's later love interest Hetty Merton: 'He told her once that he was wicked, and she had laughed at him, and answered that wicked people were always very old and very ugly' (Wilde 175). Not only does Wilde criticise the male gaze, but he also criticises these imitations in their female counterparts, who suffer under Dorian's exploits. However, due to their vulnerable positions and tragic outcomes, Sybil and Hetty are not held responsible for these misled notions; they are arguably conditioned by the patriarchal society, built on appearances, objectification, and fairy tales of the handsome Prince Charming, who always rescues the adored damsel. Indeed, Wilde still emphasises to a far greater extent the destructive authority of the male gaze over the female. Later in the novel, the name 'Prince Charming' becomes a grimly ironic statement thrown at Dorian by a prostitute that knows first-hand the true character behind the pleasing face (Wilde 150). This name has come to haunt him as he starts to become weary of the life he has led, feeling the first inklings of regret.

Through Marian Halcombe's narration in The Woman in White, the reader switches from Walter's perspective to her authoritative female gaze. This is a proto-feminist notion by Collins, as Marian becomes the heroine attempting to protect her sister from her tyrannical husband. Like Walter, she also scrutinises the physical 'blemishes' of others. After moving to the Glyde estate with her newly wedded sister, Marian rants about the disagreeability of Count Fosco being 'immensely fat' as she has 'always especially disliked corpulent humanity' (Collins 1860, 217). Her annoyance is increased by the popular assumption 'that no people but amiable people ever get fat,' whereas she argues against 'these absurd assertions by quoting examples of fat people who were as mean, vicious, and cruel, as the leanest and the worst of their neighbours' (Collins 1860, 217-218). As Marian seeks to destabilise one stereotype - that all overweight people are good - she ironically replaces it with another - that all overweight people are bad. It is not stereotyping that makes Marian angry, but rather the fact that it is not a generalisation that suits her personal opinion of Mr Fosco. Marian's gaze here causes a conundrum in current gender scholarship: Suzanne Moore states that there is a 'strange absence' of 'material on how women look at men,' presuming that 'to suggest that women actually look at men is to stumble into a theoretical minefield which holds sacred the idea that in the dominant media the look is always already structured as male' (45). Marian's observation, therefore, poses a significant question for feminist critics of the female gaze. Previously being housekeeper of the Fairlie household, and exercising substantial authority while Mr Fairlie retired behind the scenes, Marian could be read as a power figure, butting heads with a new power when hers has been reduced in the Glyde estate in favour of the highly influential Count Fosco. Therefore, much like Walter's objectifying gaze when he entered the Fairlie estate in a subordinate role, Marian seems to subconsciously resent Count Fosco as a foreign outsider who enjoys more privilege than she. This is made even more apparent by the fact that Lord Glyde is not 
subject to the same scrutiny of his physical appearance, yet he is the one who constantly treats Marian's younger sister with such cruelty.

In contrast to Laura Fairlie's demure femininity, the female gaze is likewise exercised through Marian's silent rebellion against the authoritarian rule of Sir Glyde and his privileged friend Count Fosco. It is, however, hard to accept this action as one of a woman exercising her free mind and selfpossession in a feminist sense, when this gaze becomes so derogatory, revealing that women, like men, can be harsh critics of the opposite sex, conditioned by prejudices of class, power, and race. Both Walter and Marian rely on physical observation to distinguish between the story's heroes, love interests, villains, and friends. While Marian admits that Fosco is easily likeable, his obesity is the first of a long list of peculiarities that informs her suspicion that he is not who he claims to be. As the following chapters reveal her suspicions to be correct, it reaffirms her bias that obese men have cruel characters. If we are to question the reliability of Walter's narration, then we should also do the same with Marian's.

Discussions on the female gaze are further complicated when we consider several of Collins' other novels. For example, Collins's later novel The Law and the Lady (1875) is a female detective novel narrated in first person by the protagonist sleuth Valeria Brinton, a self-effacing woman who discovers her own authorial gaze through her investigation of her husband's mysterious past. Joseph A. Kestner has argued that 'the specific nature of the female detective narrative is to address the practise of the woman having the power of the gaze as she executes her professional - private or official - responsibility of surveillance' (17). In this novel, the acts of observing, looking in mirrors and reflecting the self through other people's gazes are recurring themes. In her eyes, Valeria finds much of herself to scrutinise, referring to herself in the third person so that her self, her personal identity, and her body, her physique, appear to be strangers to each other: she states that 'her eyes are of so dark a blue that they are generally mistaken for black,' and that 'her nose just inclines towards the aquiline bend, and is considered a little too large by persons difficult to please' (Collins 1875, 16). These remarks reiterate the strict measurements of beauty that Walter Hartright inflicts upon Laura and Marian in The Woman in White. Through Valeria's observation, the reader can understand how the male gaze upon can materialise into a self-effacing perception of one's physical merits, and how this affects the subject's behaviour and sense of self. Dorian Gray's vanity is affected by people's remarks on his beauty. Likewise, Valeria's self-reflection reveals that she, for the most part, agrees with how others superficially see her. Valeria quickly becomes the heroine of the story due to her modesty, and readers empathise with a woman who struggles to fit into a critical world. Furthermore, she states that in this self-observation she has 'done [her] best to keep clear of two vanities-the vanity of depreciating and the vanity of praising my personal opinion' (Collins 1875,17 ). Revealed is a woman who is so self-conscious of criticism that the fear of looking into the mirror for too long becomes a neurosis. Valeria's characterisation aligns with John Berger's argument that 'from earliest childhood,' a woman is 'taught and persuaded to survey herself continually... because how she appears to others and particularly how she appears to men, is a crucial importance to what is normally thought of, as the success of her life' (Ways of Seeing 00:02:37-56). But as the mystery of her husband's past ensues, the reader sees Valeria defying these notions and becoming an agent of her own self-determination.

The Law and the Lady arguably achieves the status of 'New Woman' writing that, in John M. L. Drew's opinion, Dorian Gray might have achieved, had the main character been a 'female beauty' rather 
than a man who 'breaks free from the passive stranglehold of male gazes' (xvii). Nonetheless, the novel still has plenty to say about the dire consequences of the male gaze: since it is under the tutelage of these older men that Dorian becomes corrupt, Wilde suggests that superficiality is something that is taught, rather than something innate. Furthermore, the sexually charged, homoerotic undertones of the novel signify the influence of older over younger men, alluding thus to issues of inequality within gay relationships. Externally, these homosexual relationships are prejudiced against the heterosexual relationships. Towards the end of the novel, for example, there are rumoured scandals between Dorian and wealthy men that have fled the country in shame, while the married upper-class women with whom Dorian also engages in extra-marital affairs are not subjected to the same shame. These relationships add another layer to the intricate workings of the social hierarchy and the male and female gazes in Victorian London. While Drew's comment sheds light on the advanced politics of the novel, nineteenthcentury audiences were only just becoming conscious of feminist critique, and it would take another hundred years for queer studies to assert its legitimacy. In light of this, Drew argues that, because Dorian is not a woman, his 'refusal to conform' to the 'passive stranglehold of male gazes' could possibly 'confuse' readers (xvii). Yet Dorian does conform. Under Lord Henry's tutelage and the constant, flattering attention that he receives from London society, he is taught to indulge in the excesses of youth and beauty available to a man born into privilege and status. It is no wonder, therefore, that he very quickly becomes the sociopathic villain of the tale. Although Dorian is not entirely the fin-de-siècle equivalent of Narcissus, the lesson to be learnt remains the same. This is most evident at the end of Wilde's novel, when Dorian begins to feel the guilty burden of the life he's led: 'It was his beauty that had ruined him, his beauty and the youth that he had prayed for. But for those two things, his life might have been free from stain' (175).

There is also a lesson to be learned from The Woman in White. As Matthew Sweet states, this novel reveals 'the ease with which identities could be obliterated or concealed,' and the 'vulnerability of women under a legal system that afforded them no status' (xxiv). Collins's proto-feminist story criticises this legal system that makes women vulnerable to the 'threat of wrongful incarceration in a madhouse' (Sweet xxvi). Walter's narration makes it clear that the injustice of this practice is conditioned by class status. After Walter discovers that Laura is not dead and they are reunited, his rejoicing turns into lamenting over the lost 'youth and beauty of her face' following the ordeal she has suffered (Collins Woman in White 434). This experience has made her look much more like Anne Catherick than ever before. That Laura, a beautiful young lady of the upper classes, should be reduced to the image of a mad woman is a cause of great sadness to Walter. What also makes this story distinct is that even a man like Walter, who claims to be protecting Laura from the exploitation of powerful men, could have ulterior motives. The story consciously shows that the act of gazing can be easily misconstrued, and that true danger is in the words that people choose to speak, and how easily it could all be lies. The observation and interpretation of appearances are merely used in this novel for the self-justification of their narrators. The novel ends with one last diary entry, in which Walter delights in discovering that $\mathrm{Mr}$ Fairlie has died, and that he will now inherit a large fortune (Collins 1860, 626-627). His principles have become clear to the reader by this point. But now it is far too late - the story is over.

Ultimately, the plotlines of these stories would be not be the same without the gaze. There would be no painting, nor a traded soul, if no one had remarked on Dorian's beauty. Likewise, Laura Glyde 
would not have been incarcerated in an institution if it were not for Lord Glyde's perception of her disposability as an inferior, nor would we suspect Walter for his coercive subjectivity. This reveals the true ramifications of the gaze. Considering that academic critique of 'the gaze' only began a century after these texts were published, one must question how much gazing still affects our daily lives, and we wonder how long we have been under-interpreting these authors. 


\section{Works Cited}

Berger, John. Ways of Seeing. The Viking Press, 1972.

Collins, Wilkie. The Law and the Lady. Elecbook Classics ed., The Electric Book Company, 1875.

ProQuest Ebook Central, https://ebookcentral-proquestcom.libraryproxy.griffith.edu.au/lib/griffith/detail.action?docID $=3008534$.

--. The Woman in White. Edited by Matthew Sweet, Penguin Classics ed, Penguin Publishers, 1860.

Craft, Christopher. 'Come See About Me: Enchantment of the Double in The Picture of Dorian Gray.' Representations, vol. 91, 2005, pp. 109-136. ProQuest, http://search.proquest.com.libraryproxy.griffith.edu.au/docview/222833206?accountid=14.5 43

Drew, John M. L. Introduction. The Picture of Dorian Gray, by Oscar Wilde, Wordsworth Editions Limited, 2001, pp. x-xxxi.

‘Episode 1.’ Ways of Seeing, created by John Berger, episode 1, BBC Two, 1972. YouTube.

'Episode 2.' Ways of Seeing, created by John Berger, episode 2, BBC Two, 1972. YouTube.

'Episode 3.' Ways of Seeing, created by John Berger, episode 3, BBC Two, 1972. YouTube.

Heller, Tamar. Dead Secrets: Wilkie Collins and the Female Gothic. Yale University Press, 1992.

Kestner, Joseph A. Sherlock's Sisters: The British Female Detective, 1864-1913, Routledge, 2016.

ProQuest Ebook Central, https://ebookcentral-proquestcom.libraryproxy.griffith.edu.au/lib/griffith/detail.action?docID=4816757

Moore, Suzanne. 'Here's Looking at You, Kid!' The Female Gaze: Women as Viewers of Popular Culture. Edited by Lorraine Gamman and Margaret Marshment, The Women’s Press, 1988, pp. 44-59.

Sweet, Matthew. Introduction. The Woman in White, by Wilkie Collins, edited by Sweet, Penguin Publishers, 2003, pp. xiii-xxxi.

Wilde, Oscar. The Picture of Dorian Gray. Wordsworth Classics ed., Wordsworth Editions Limited, 1890. 


\section{Author Biography}

Leah Henderson is a PhD candidate at Griffith University, Brisbane, Australia. Researching in the field of humanities, her interests include gender studies, popular culture, gothic literature, serialised fiction, and cultural history. She has presented a paper at the University of Warwick, and this is her debut publication. 